\title{
Enhancement of the biocontrol agent Candida oleophila (strain O) survival and control efficiency under extreme conditions of water activity and relative humidity
}

\author{
Rachid Lahlali $^{\text {a,b,*, M. Haïssam Jijakli }}{ }^{\text {a }}$ \\ a Plant Pathology Unit, Gembloux Agricultural University, Passage des Déportés 2, 5030 Gembloux, Belgium \\ b Plant Biology Research Institute, Department of Biological Sciences, Montreal University, 4101 Sherbrooke Est, Montréal, Que., H1X 2B2 Canada
}

\section{A R T I C L E I N F O}

\section{Article history:}

Received 20 May 2008

Accepted 23 July 2009

Available online 29 July 2009

\section{Keywords:}

C. oleophila strain 0

Protectant substances

Relative humidity

Water activity

Pre-harvest

\begin{abstract}
A B S T R A C T
The objective of this work is to evaluate the ability of some additive substances in protecting the biocontrol agent Candida oleophila (strain O) against the adverse effects of environmental factors, such as water activity $\left(a_{w}, 0.93\right.$ and 0.98$)$ and relative humidity (75\% and $\left.98 \%\right)$. The protection obtained with various protectant substances, skimmed milk (SM), peptone, maltose, sucrose, sorbitol, lactose and polyethylene glycol was assayed under in vitro and in vivo conditions. The yeast cells with the highest level of protecting agents ( $1 \%$ ) had higher viability than those with low protectant levels $(0.1 \%$ and $0.5 \%)$. SM, sucrose and sorbitol improved significantly the C. oleophila survival on apple fruit surface by $80.8 \%, 42.26 \%$ and $37.27 \%$ and gave a significant protection (from $96 \%$ to $100 \%$ ) against Penicillium expansum under dried conditions. The highest strain O density and efficacy was obtained with SM. Under experimental conditions reflecting practical conditions, SM applied in combination with the strain $\mathrm{O}$ resulted in improved biocontrol efficacy by $74.65 \%$. Therefore, SM could be used as material substrate with the best sugar protectants during the formulation process of this antagonistic yeast for eventual pre-harvest application.
\end{abstract}

(c) 2009 Elsevier Inc. All rights reserved.

\section{Introduction}

The yeast Candida oleophila strain O was isolated from the surface of Golden Delicious apples and selected for its high and reliable biocontrol activity against Botrytis cinerea and Penicillium expansum, two serious worldwide pathogens of stored apple and pears (Jijakli et al., 1993). The underlying mechanisms responsible for its biocontrol activity have been determined using $B$. cinerea/ apple as a model and using microbiological, biochemical, genetic and molecular approaches. Competition for nutrients and space seem to be the main modes of action of strain $O$ (Jijakli et al., 1993; Massart et al., 2005). In order to specifically track the population dynamics of this strain after its application on apples, different monitoring systems have been developed (Massart et al., 2005). Strain O was also found to be very effective for controlling Penicillium digitatum and Penicillium italicum, two devastating post-harvest pathogens of citrus (Lahlali et al., 2004; Lahlali et al., 2005a). Its biocontrol activity has been shown to be very efficient for post-harvest applications where environmental conditions are generally well controlled. For pre-harvest applications, however, strain $\mathrm{O}$ population density and efficacy during a 2-year

\footnotetext{
* Corresponding author. Address: Plant Biology Research Institute, Department of Biological Sciences, Montreal University, 4101 Sherbrooke Est, Montréal, Que., Canada H1X 2B2.

E-mail addresses: r.lahlali@hotmail.com, lahlali.r@gmail.com (R. Lahlali).
}

trial were largely influenced by meteorological conditions (Jijakli et al., 2002). In pre-harvest applications, the biocontrol agent (BCA) will face large changes in temperature, relative humidity, light intensity, etc. To be successful in such application, the optimal and limits of environmental conditions in which strain $\mathrm{O}$ might develop must be determined. Water availability and temperature are among the main factors able to alter strain $\mathrm{O}$ growth and establishment. Recently, Lahlali et al. (2008) proposed a validated predictive model for controlling the population density of BCA C. oleophila in field conditions $48 \mathrm{~h}$ after its application on apples fruit according to temperature, relative humidity and its initial concentration of application. The effect of initial yeast concentration and relative humidity appears more significant than that of temperature on final yeast density on apple fruit surface.

Commercial formulation of BCAs should possess adequate shelf life and retain biocontrol activity similar to that of fresh cells of the agents (Li and Tian, 2006, 2007).

Exogenous protectants play an important role in the conservation of viability during and after the freeze-drying process. Various groups of substances, such as sulfoxides, alcohols and their derivates, monosaccharides and polysaccharides, amino acids, peptides, glycoproteins and compounds have shown protective action. Therefore, numerous researchers reported that the stress tolerance of microorganisms could be improved by inducing the accumulation of intracellular sugars (Teixidõ et al., 1998a,b). Trehalose, a non-reducing disaccharide and a major reserve carbohydrate, has been shown to be effective as a protectant metabolite 
against environmental stresses, such as heat, dehydration, freezing and hyperosmotic stress (Kown et al., 2003).

Sugars including various monosaccharides and disaccharides are usually used as exogenous protectants prior to the freeze-drying process. Direct interactions between sugar molecules and membrane phospholipids, or sugar molecules and proteins, and nitrification of sugars in a dry state are thought to be the main protective mechanisms (Crowe et al., 1990). However, there is little information about the effect of exogenous protective agents on viability and biocontrol efficacy of antagonists subjected to conditions of low water availability and relative humidity.

In our previous works, the effect of water activity, temperature and relative humidity has been successfully evaluated on the in vitro and in vivo growth of B. cinerea and (Lahlali et al., 2007a, 2006b), P. expansum (Lahlali et al., 2005b, 2006b), P. digitatum and P. italicum (Lahlali et al., 2006a) and Pichia anomala strain $\mathrm{K}$ and $C$. oleophila strain $O$ (Lahlali et al., 2008). The obtained results showed that both antagonistic yeast $P$. anomala and $C$. oleophila are highly sensitive to water stress as compared to four Pencillium species and B. cinerea (Lahlali et al., 2007b). These studies have enabled us to determine and compare the ecological niches of these economically important pathogens. Accordingly, this study has been undertaken in order to (i) evaluate the ability of protectant substances to improve strain $\mathrm{O}$ viability at low values of water activity and relative humidity (ii) determine its biocontrol efficacy against $P$. expansum at low relative humidity when it is applied in combination with protectant substances and (iii) determine the best additive, which could be used as support material in the formulation of strain $\mathrm{O}$ as a biocontrol product.

\section{Materials and methods}

\subsection{Microorganisms}

Candida oleophila (strain $\mathrm{O}$ ) was isolated from the surface of $\mathrm{cv}$. Golden Delicious apples at the Plant Pathology Unit (Gembloux Agricultural University, Belgium) and identified by the Industrial Fungi \& Yeast collection (bccMTM/MUCL, Belgium). Stock cultures were stored at $4{ }^{\circ} \mathrm{C}$ on Potato dextrose Agar (PDA, Merck, Darmstadt, Germany) plates. Before an experiment, this strain was grown on PDA at $25{ }^{\circ} \mathrm{C}$ for three successive subcultures under the same conditions with an interval of $24 \mathrm{~h}$. Before application to apples, yeast colonies were flooded with sterile distilled water (SDW) and scraped from Petri plates. The final concentration of this strain was adjusted according to optical density measurements with an UltrospecII spectrophotometer (LKB Biochron Ltd, Uppsala, Sweden) at $595 \mathrm{~nm}$ (Jijakli and Lepoivre, 1998).

Penicillium expansum (strain vs2) was isolated from decayed apple fruits (Plant Pathology Unit, FUSAGx, Belgium). For long-term storage, the strain was placed at $-70^{\circ} \mathrm{C}$ in tubes containing $25 \%$ glycerol. During experiments, the initial conidial inoculum was taken from Petri-dish cultures on PDA medium, preserved at $4{ }^{\circ} \mathrm{C}$ for no more than 6 months. The conidial suspension was prepared from $10 \pm 1$-day-old culture grown at $25^{\circ} \mathrm{C}$ in SDW containing 0.05\% Tween 20 .

\subsection{Medium and fruits preparation}

The basic medium used for the present study was PDA with a water activity $\left(a_{w}\right)$ of 0.995 . Water activity is a measure of the energy status of the water in a system. It is defined as the vapor pressure of water above a sample divided by that of pure water at the same temperature; therefore, pure distilled water has a water activity of exactly one (Hallsworth and Magan, 1996). Water activity $\left(a_{w}\right)$ was modified by the addition of increasing amounts of glycerol to obtain levels of 0.980 and 0.930 at $25^{\circ} \mathrm{C}$ (Lahlali et al., 2005b, 2006a, 2007a). The $a_{w}$ of all media was measured by a CX 3 Aqua Lab device (Decagon Devices, Inc.).

'Golden Delicious' apple fruits were disinfected by soaking for 2 min in sodium hypochlorite solution (10\%), then rinsed twice in SDW.

\subsection{Efficacy of protectant substances under low water activity}

The protectant substances used in this work were peptone, skimmed milk (SM), sorbitol, lactose, sucrose, maltose and polyethylene glycol. These protectants were tested in combination with C. oleophila strain $\mathrm{O}$ at three concentrations $1 \%, 0.5 \%$, and $0.1 \%$. Before the experiment, all additives were prepared in falcon tubes of $15 \mathrm{ml}$ containing $10 \mathrm{ml}$ of SDW and then autoclaved at $120^{\circ} \mathrm{C}$ during $20 \mathrm{~min}$. For each protectant-strain $\mathrm{O}$ combination, the final concentration was adjusted to $10^{4} \mathrm{CFU} / \mathrm{ml}$. An aliquot of $100 \mu \mathrm{l}$ of serial 10 -fold dilutions from each prepared mixture was spread over the modified PDA medium after incubation $48 \mathrm{~h}$ at $25^{\circ} \mathrm{C}$ and then sealed with the polyethylene bags in order to avoid the water losses. The control contains only strain $\mathrm{O}$. Petri dishes were incubated at $25{ }^{\circ} \mathrm{C}$ for varying time depending on the $a_{w}$ of medium. For non-modified PDA medium and $a_{w}$ of 0.98 , dishes were incubated for $72 \mathrm{~h}$, and for 5-6 days for media with $a_{w}$ of 0.93 . The experiments were performed in triplicate for each protectantstrain $0-a_{w}$ combination and the trial was repeated twice over time. The cell viability was calculated using the following formula: viability $=[$ (colony number in the presence of protectant $) /$ (colony number in non-stressed medium) (control) $] \times 100$.

\subsection{Efficacy of protectant substances under low relative humidity}

In this experiment, all protectant substances were evaluated at both extreme concentrations $1 \%$ and $0.1 \%$. The concentration of $C$. oleophila strain $\mathrm{O}$ protectant biocontrol combination was adjusted to $10^{7} \mathrm{CFU} / \mathrm{ml}$. After drying, disinfected apple fruits were treated by dipping into $400 \mathrm{ml}$ suspension of strain O-protectants combination for $2 \mathrm{~min}$. Treated fruits were placed in desiccator with different relative humidities ( $\mathrm{RH}, 75 \%$ and $98 \%$ ). The approximate value of equilibrium relative humidity (98\% and $75 \%$ ) inside the desiccator was controlled by means of saturated salt solutions: $\mathrm{K}_{2} \mathrm{SO}_{4}(98 \%)$ and $\mathrm{NaCl}$ (75\%). There were four apples for each desiccator and RH treatment. In this experiment, two controls of strain $\mathrm{O}$ without protectant substances were used one each at $\mathrm{RH}$ of $75 \%$ and $98 \%$. All treatments were kept at $25^{\circ} \mathrm{C}$. After $24 \mathrm{~h}$ of incubation, four apples per treatment were washed in $1 \mathrm{~L} \mathrm{KBP}$ buffer $\left[\mathrm{KH}_{2} \mathrm{PO}_{4}(0.05 \mathrm{M}), \mathrm{K}_{2} \mathrm{HPO}_{4}(0.05 \mathrm{M})\right.$ and $0.05 \%(\mathrm{wt} / \mathrm{v})$ Tween 80 , $\mathrm{pH}$ 6.5] on a rotary shaker for $20 \mathrm{~min}$ at $120 \mathrm{rpm}$. Serial 10 -fold dilutions were prepared from $1 \mathrm{ml}$ washing buffer and were plated in triplicate on PDA medium. Petri dishes were kept at $25^{\circ} \mathrm{C}$ for $2-$ 3 days. This experiment was twice repeated. The surface area of the apple was calculated as follows: [Area $\left(\mathrm{cm}^{2}\right)=0.488 \times$ volume of displaced water $(v / v)+66.1(r=0.99)]$ (Lahlali et al., 2008, 2009). Population sizes were expressed as $\mathrm{cfu} / \mathrm{cm}^{2}$. This step was carried out in triplicate for each treatment.

\subsection{Efficacy of protectant substances against P. expansum}

Disinfected apple fruits were wounded at two equidistant points of equatorial zone (2-3 $\mathrm{mm}$ in diameter, $4 \mathrm{~mm}$ in depth) using a cork borer instrument. Each wound was treated with $10 \mu \mathrm{l}$ of strain $\mathrm{O}$ suspension at a concentration of $10^{7} \mathrm{CFU} / \mathrm{ml}$ with or without protectant. The control treatment was only inoculated with the same suspension of SDW. Inoculation with P. expansum was carried out $24 \mathrm{~h}$ after biological treatment. Each wound received an aliquot of $10 \mu \mathrm{l}$ from a pathogen suspension of 
$10^{5}$ spores $/ \mathrm{ml}$. Treated fruits were stored at a temperature of $24^{\circ} \mathrm{C}$ from 11 days. There were four apples per treatment. Two trials were conducted over time with three replicates per treatment.

\subsection{Efficacy of protectant substances against P. expansum under low relative humidity}

Treated apple fruits with strain $\mathrm{O}$ alone $\left(10^{8} \mathrm{CFU} / \mathrm{ml}\right), \mathrm{SM}(1 \%)$ or in combination were wounded at two equidistant points in the equatorial zone (2-3 $\mathrm{mm}$ in diameter, $4 \mathrm{~mm}$ deep) using a cork borer $24 \mathrm{~h}$ after biological treatment and then followed by pathogen inoculation $24 \mathrm{~h}$ later. Wounds were inoculated with $10 \mu \mathrm{l}$ of pathogen suspension $\left(10^{5}\right.$ spores $\left./ \mathrm{ml}\right)$. These sequences of treatment were designed to reflect practical conditions (Lahlali et al., 2009). Desiccators containing various treatments were sealed and kept at $24^{\circ} \mathrm{C}$. Generally, there are eight treatments. After 11 days of incubation, the lesion diameters were recorded for each treatment.

\subsection{Statistical analysis}

One way ANOVA procedure using SAS software (SAS Institute, Inc., Cary, NC, USA) was performed for viability (\%), population density $\left(\mathrm{CFU} / \mathrm{cm}^{2}\right)$ and lesion diameter $(\mathrm{mm})$ and when significant effects were observed, the Newman-Keuls test was used for the mean separation $(P \leqslant 0.05)$.

\section{Results}

\subsection{Efficacy of protectant substances at low water activity}

The efficiency of selected protectant substances in protecting $C$. oleophila strain $\mathrm{O}$ against low water activity was evaluated 'in vitro' at $0.1 \%, 0.5 \%$ and $1 \%$ application concentrations. At $a_{w}$ of 0.98 , all protectants gave higher viability of strain $\mathrm{O}$ in comparison with strain $O$ alone (Table 1 ). Strain $O$ cells showed the highest viability when protectants were applied at a concentration of $1 \%$. SM, maltose and sucrose as protectants resulted in the greatest viability for strain $O$ cells at high $a_{w}(0.98)$. The corresponding viabilities were $200 \%, 191 \%$ and $189 \%$ when they were applied at $1 \%$ in modified medium as compared to other treatments tested here (Table 1 ).

At $a_{w}$ of 0.93 , SM gave better protection than other sugars when it was applied at $1 \%$. The results also showed no significant difference between sucrose and peptone (Table 1 ). At $0.5 \%$, all protectant substances improved significantly the strain $O$ viability, except lactose. This result was confirmed at $0.1 \%$. However, all additives showed to be significantly different from the control and from the lactose, even if the recorded viability was altogether lower than
$100 \%$. Peptone resulted in the nominally highest viability (94\%) at $0.1 \%$ application rate and an $a_{w}$ of 0.93 (Table 1 ).

\subsection{Efficacy of protectant substances at low relative humidity}

Trials were carried out on apple fruits in order to evaluate the ability of various protectant substances in protecting the strain $\mathrm{O}$ against low $\mathrm{RH}$. Strain $\mathrm{O}$ mixtures with various additives at $1 \%$ and $0.1 \%$ were applied to fruits, placed in desiccators at $\mathrm{RH}$ of $75 \%$ and $25{ }^{\circ} \mathrm{C}$ and then compared with both controls (strain $\mathrm{O}$ alone at $\mathrm{RH}$ of $75 \%$ and $98 \%$ ) (Fig. 1). Variance analysis showed that only SM (1\%), sucrose (1\%) and sorbitol (1\%) improved significantly the viability of strain $\mathrm{O}$ cells at dried conditions ( $\mathrm{RH}$ of $75 \%$ ), but this increase in strain $O$ population density remains significantly lower than that observed with strain $\mathrm{O}$ alone at wet conditions (RH of 98\%).

\subsection{Efficacy of protectant substances against P. expansum}

The biocontrol efficacy of strain $\mathrm{O}$ applied together with different protectant substances was evaluated against $P$. expansum. Statistical analysis show insignificant difference between the obtained efficacy of a strain O-protectant mixtures and strain $\mathrm{O}$ alone, except at concentration of $1 \%$ (Table 2). However, a significant effect of additive substances used in combination with strain $\mathrm{O}$ was observed in comparison with the untreated control with yeast. The best control efficacy was obtained when strain $\mathrm{O}$ was applied together with SM.

\subsection{Efficacy of protectant substances against P. expansum at low relative humidity}

SM was the protectant used in this experiment due to the great ability to protect strain $\mathrm{O}$ against the low water availability in 'in vitro' and 'in vivo' conditions. Likewise, its combined application did not influence statistically its effectiveness against apple blue rot. The average diameter of the lesions caused by $P$. expansum was significantly higher at $\mathrm{RH}$ of $75 \%$ as compared to that of $98 \%$ (Table 3$)$. The addition of SM (1\%) alone increased significantly the apple rot infection under dried conditions (RH of 75\%). However, at high RH (98\%), no significant difference was observed between these treatments. The application of SM (1\%) in combination with strain $\mathrm{O}$ significantly improved biocontrol efficacy against $P$. expansum under dry conditions (low $\mathrm{RH}$ ), which reflects the common natural conditions.

Table 1

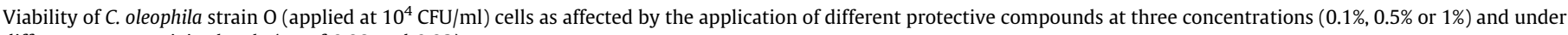
different water activity levels ( $a_{w}$ of 0.98 and 0.93 ).

\begin{tabular}{|c|c|c|c|c|c|c|}
\hline \multirow[t]{3}{*}{ Protectants } & \multicolumn{6}{|c|}{ Concentrations (\%) } \\
\hline & \multicolumn{3}{|c|}{ Water activity $\left(a_{w}\right) 0.98$} & \multicolumn{3}{|c|}{ Water activity $\left(a_{w}\right) 0.93$} \\
\hline & $0.1 \%$ & $0.5 \%$ & $1 \%$ & $0.1 \%$ & $0.5 \%$ & $1 \%$ \\
\hline PEG & $95.78^{a}$ & $100.94^{d}$ & $166.07^{f}$ & $90.00^{\mathrm{a}}$ & $102.11^{\mathrm{b}}$ & $144.67^{d}$ \\
\hline Maltose & $106.83^{\mathrm{a}}$ & $126.67^{\mathrm{a}}$ & $189.78^{\mathrm{bc}}$ & $88.11^{\mathrm{a}}$ & $92.78^{\mathrm{b}}$ & $160.50^{c}$ \\
\hline Skimmed milk & $106.94^{\mathrm{a}}$ & $127.11^{\mathrm{a}}$ & $200.71^{\mathrm{a}}$ & $92.17^{\mathrm{a}}$ & $102.61^{\mathrm{b}}$ & $192.33^{\mathrm{a}}$ \\
\hline Peptone & $104.84^{\mathrm{a}}$ & $110.44^{\mathrm{bc}}$ & $185.84^{\mathrm{cd}}$ & $94.00^{\mathrm{a}}$ & $119.89^{\mathrm{a}}$ & $168.17^{\mathrm{b}}$ \\
\hline Sucrose & $106.00^{\mathrm{a}}$ & $106.16^{\mathrm{cd}}$ & $191.78^{\mathrm{b}}$ & $88.39^{a}$ & $98.72^{\mathrm{b}}$ & $170.26^{\mathrm{b}}$ \\
\hline Sorbitol & $104.83^{\mathrm{a}}$ & $118.83^{\mathrm{ab}}$ & $183.55^{\mathrm{d}}$ & $86.00^{\mathrm{ab}}$ & $94.67^{\mathrm{b}}$ & $148.84^{\mathrm{d}}$ \\
\hline Lactose & $101.17^{\mathrm{a}}$ & $109.67^{\mathrm{bc}}$ & $137.99^{\mathrm{e}}$ & $72.17^{c}$ & $80.89^{c}$ & $123.00^{\mathrm{e}}$ \\
\hline Control & $97.85^{\mathrm{a}}$ & $97.85^{\mathrm{cd}}$ & $97.85^{\mathrm{g}}$ & $75.56^{\mathrm{bc}}$ & $75.56^{\mathrm{c}}$ & $75.6^{\mathrm{f}}$ \\
\hline
\end{tabular}

"In the same column, treatments having the same letter are not significantly different according to Newman and Keuls test $(P \leqslant 0.05)$

P.E.G., polyethylene glycol. 


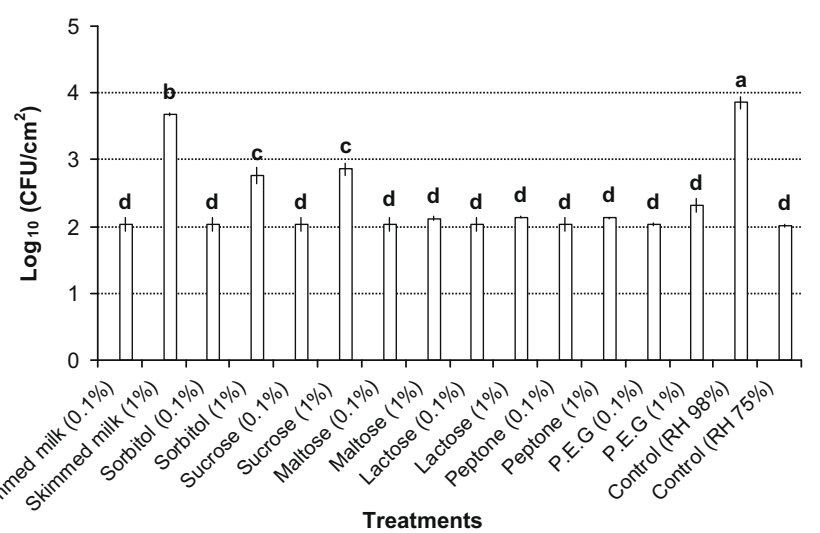

Fig. 1. Strain O population densities obtained on apple fruit surface at $\mathrm{RH}$ of $75 \%$, after applying $C$. oleophila strain $\mathrm{O}\left(10^{7} \mathrm{CFU} / \mathrm{ml}\right)$ in combination with various protectants at both concentrations $1 \%$ and $0.1 \%$. Controls are strain 0 , applied alone at $\mathrm{RH}$ of $75 \%$ and $98 \%$. Bars represent the standard error of the means. Treatments having the same letters are not significantly different according to Newman and Keuls test $(P \leqslant 0.05)$.

Table 2

Efficacy of strain $\mathrm{O}$ formulations, applied in mixture with different concentrations of protectants, against $P$. expansum inoculated at with $10 \mu \mathrm{l} /$ wound $\left(10^{5} \mathrm{spores} / \mathrm{ml}\right)$.

\begin{tabular}{|c|c|c|c|}
\hline \multicolumn{4}{|l|}{ Lesion diameter (mm) } \\
\hline Treatments & $1 \%$ & $0.5 \%$ & $0.1 \%$ \\
\hline Sorbitol $+C$. oleophila (strain 0 ) & $1.08^{\mathrm{c}}$ & $3.33^{\mathrm{b}}$ & $3.33^{\mathrm{b}}$ \\
\hline Sucrose $+C$. oleophila $($ strain 0$)$ & $1.75^{\mathrm{c}}$ & $1.67^{\mathrm{b}}$ & $1.67^{\mathrm{b}}$ \\
\hline P.E.G. + C. oleophila (strain O) & $4.00^{c}$ & $3.75^{\mathrm{b}}$ & $3.75^{\mathrm{b}}$ \\
\hline Lactose $+C$. oleophila $($ strain 0$)$ & $5.67^{\mathrm{bc}}$ & $7.00^{\mathrm{b}}$ & $4.58^{\mathrm{b}}$ \\
\hline Maltose $+C$. oleophila $($ strain 0$)$ & $4.17^{\mathrm{c}}$ & $10.2^{\mathrm{b}}$ & $4.25^{\mathrm{b}}$ \\
\hline Skimmed milk $+C$. oleophila $($ strain 0$)$ & $0.00^{c}$ & $0.86^{\mathrm{b}}$ & $0.00^{\mathrm{b}}$ \\
\hline Peptone $+C$. oleophila $($ strain $\mathrm{O})$ & $13.33^{\mathrm{b}}$ & $13.75^{\mathrm{b}}$ & $11.08^{\mathrm{b}}$ \\
\hline C. oleophila (strain $\mathrm{O})$ & $1.00^{\mathrm{c}}$ & $1.00^{\mathrm{b}}$ & $1.00^{\mathrm{b}}$ \\
\hline Control (pathogen) & $43.2^{\mathrm{a}}$ & $43.2^{\mathrm{a}}$ & $43.2^{\mathrm{a}}$ \\
\hline
\end{tabular}

"In the same column, treatments having the same letter are not significantly different according to Newman and Keuls test $(P \leqslant 0.05)$.

P.E.G., polyethylene glycol.

\section{Table 3}

Biocontrol efficacy of $C$. oleophila strain $\mathrm{O}\left(10^{8} \mathrm{CFU} / \mathrm{ml}\right)$ applied with/out SM (1\%) against $P$. expansum, applied at $10 \mu \mathrm{l} /$ wound $\left(10^{5}\right.$ spores $\left./ \mathrm{ml}\right)$, at $\mathrm{RH}$ of $75 \%$ and $98 \%$. The pathogen inoculation was made $24 \mathrm{~h}$ after wounding. Treatments having the same letters are not significantly different according to Newman and Keuls test $(P \leqslant 0.05)$.

\begin{tabular}{ll}
\hline Treatments & Lesion diameter (mm) \\
\hline $\begin{array}{l}\text { C. oleophila strain O + skimmed milk (1\%)+ } \\
\text { relative humidity (98\%) }\end{array}$ & $0.62^{\mathrm{f}}$ \\
$\begin{array}{l}\text { C. oleophila strain O + skimmed milk (1\%)+ } \\
\text { relative humidity (75\%) }\end{array}$ & $7.00^{\mathrm{e}}$ \\
Skimmed milk (1\%) + relative humidity (98\%) & $16.75^{\mathrm{c}}$ \\
Skimmed milk (1\%) + relative humidity (75\%) & $40.37^{\mathrm{a}}$ \\
C. oleophila strain O + relative humidity (98\%) & $1.25^{\mathrm{f}}$ \\
C. oleophila strain O + relative humidity (75\%) & $10.5^{\mathrm{d}}$ \\
Relative humidity (98\%) & $14.12^{\mathrm{c}}$ \\
Relative humidity (75\%) & $27.62^{\mathrm{b}}$ \\
\hline
\end{tabular}

\section{Discussion}

Infection by post-harvest pathogens often arises during crop harvesting (Teixidõ et al., 1999; Ippolito and Nigro, 2000); therefore it would be advantageous to apply the BCA prior the harvest process in order to colonize wounds before the arrival of the pathogens. Such pre-harvest application would have numerous benefits, such as decreasing the level of damages, which can occur during the post-harvest treatment. In order to be successful, the inoculum of BCA should tolerate various environmental stresses of the orchard, including higher temperatures, lower water availability, low nutrients and ultraviolet radiations (Teixidõ et al., 1999). Bonaterra et al. (2005), reported that the application of Pantoea agglomerans to unwounded fruits was practically ineffective for controlling the blue mold when the biological treatment, subsequent wounding and pathogen inoculation were separated by long periods of low relative humidity conditions. The authors attributed the lack of efficacy to the difficulties in colonization and survival of antagonistic bacteria in the intact peel surface compared to the rapid growth observed in fresh wounds. Mercier and Wilson (1995) demonstrated the lowest growth of $C$. oleophila in old wounds of apples. Our previous research evaluated the efficacy of biocontrol agent $P$. anomala strain $\mathrm{K}$ against $P$. expansum in the laboratory in three scenarios designed to mimic practical conditions, with different periods of incubation between biological treatment, wounding of fruit surface, and pathogen inoculation. The results showed the impact of wetness on apple surfaces on $P$. anomala growth, and subsequent biocontrol efficacy against blue mold (Lahlali et al., 2009).

A substantial amount of research has been conducted on improving the resistance of BCA to abiotic stress by adaptation of growth to unfavorable osmotic conditions (Bonaterra et al., 2005). In this study, we were interested in an exogenous approach focused on the application of some protectant additives in combination with the BCA to improve its tolerance to environmental stress and, therefore, promote their establishment on apple fruit surfaces. To our knowledge, the use of additive substances has two main functions in the production of viable cells. The first is to restore damage done to the cytoplasmic membrane. The second is the biochemical protection of cells against damage caused during osmotic stress (Berny and Hennebert, 1991). Our in vitro results showed that the strain $\mathrm{O}$ viability was significantly improved at $a_{w}$ of 0.93 when it is applied in combination with various protectants. This viability varies significantly depending on the type of protectant and its applied concentration. The greatest value was obtained for all protectants at $1 \%$. However, the highest was recorded by SM. This may be due to its richness in protein, vitamins and sugars, which contributes effectively to improving the strain $O$ viability. Moreover, SM contains many solutes, such as phosphates and citrate, which may provide buffering capacity and stabilize $\mathrm{pH}$ (Zayed and Roos, 2004). Champagne et al. (1991) underlines that the protein contained in SM offers a good protection for the cell membrane toward the adverse environmental factors and restores cells affected during the dehydration and osmotic stress or the disruption of hydrogen bonds (Ray et al., 1971). Additionally, increasing the viability of the strain $\mathrm{O}$ could also be explained by the nature of polyol (sorbitol), and some sugars (sucrose, maltose, and lactose) used in this work. Sugar includes various monosaccharides and disaccharides which are usually used as exogenous protectants of BCA prior the freeze-drying process. Teixidõ et al., 1999 reported that the intracellular accumulation of certain sugars allows cells to work and survive under conditions of stress, in particular at low water availability. Similarly, Hanafusa (1985) found that the addition of certain protectant substances, such as sugars or glycerol, reduced the amount of bound water on the surface of proteins. The protectant substances may themselves form hydrogen bonds with the protein, thus substituting for water in order to maintain the stability of the protein (Font de Valdez et al., 1983).

Our in vivo results confirmed the in vitro findings and showed that, among the protectant substances tested here, only SM, sorbitol and sucrose significantly improved the strain $O$ population density on apple fruit surface at low RH (75\%) as compared with strain $\mathrm{O}$ alone. The highest density was obtained in the presence of SM. 
However, this density remains significantly lower than that observed at RH close to the saturation (98\%) without protectant substances. Additionally, applying C. oleophila strain O $\left(10^{8} \mathrm{CFU} /\right.$ $\mathrm{ml}$ ) in combination with SM (1\%) gave better protection against $P$. expansum at low $\mathrm{RH}$ under a scenario reflecting practical conditions. This result could be explained by the direct protective properties of SM against desiccation, or by improving the nutritional state of strain $\mathrm{O}$, when applied together with SM. As shown in Fig. 1, SM increased the strain O survival on apple fruit surface under stress conditions. However, a fast blue mold infection was observed on apple fruit when SM was applied alone. Abadias et al. (2001) also reported the best efficacy of Candida sake cells when it was applied in combination with SM. This product also provided the freeze-dried product with a porous structure that caused rehydration. The workers underlined the importance of using a SM as a support material in mixture with the best protectant substances. It is thought that protein contained in milk provides a protective coat for the cells (Champagne et al., 1991).

At higher relative humidity, SM (1\%) did not affect the strain $\mathrm{O}$ viability. However, a significant difference was observed between both controls (apples only inoculated with the pathogen) with the highest lesion diameter of blue decay at $\mathrm{RH}$ of $75 \%$ in comparison with $\mathrm{RH}$ of $98 \%$. This result is in disagreement with those previously reported by Lahlali et al. (2006b) and with those found under 'in vitro' conditions where the mycelial growth was positively correlated with the water activity of the medium and incubation temperature. This could be explained by the environment of the wound, which would seem to serve as a barrier protecting the fungus from the exogenous effects of $\mathrm{RH}$.

Our 'in vivo' results shown in Fig. 1 (SM, sorbitol and sucrose) are in agreement with those of Bonaterra et al. (2005). These authors showed that the osmoadaptation of $P$. agglomerans EPS125 cells in a medium containing the $\mathrm{NaCl}$ or the glycine betaine increased considerably the survival of this antagonistic yeast on the intact surface of apple fruits. This effect was highly significant under low $\mathrm{RH}$ and fluctuating $(\mathrm{RH})$ conditions, but was not significant at high RH. It has been shown that osmoadapted cells accumulated trehalose and glycine betaïne (GB) intracellularly, and that they show a higher tolerance to desiccation compared to non-osmoadapted cells. Furthermore, it also has been reported that the osmoadaptation significantly improved blue mold control under conditions where the standard biological control treatments were ineffective. The rot diameter was significantly reduced in apple fruits, which were treated with EPS125 and incubated for several days under low, high or fluctuating $\mathrm{RH}$, followed by wounding and inoculation of $P$. expansum (Bonaterra et al., 2005).

Previous research on the effect of water activity on the intracellular accumulation of endogenous solutes of $C$. sake showed a significant change in ecophysiological parameters that can affect the endogenous contents of yeast cells (Teixidõ et al., 1998a,b). These results could be used to develop an efficient and more stable biocontrol inoculum in storage with a higher resistance to desiccation. The principle of stress tolerance is based on the induction of intracellular accumulation of compatible solutes to make BCAs more tolerant to environmental stress and to maintain their cells turgor (Csonka, 1989; Miller and Wood, 1996). Generally, theses compatible solutes including polyols, sugars, aminoacids and their byproduct substances are synthesized or taken directly from the environment (Potts, 1994; Teixidõ et al., 1998b; Magan, 2001; Abadias et al., 2001). Overall, the combination of intracellular accumulation of compatibles solutes and SM, may improve the resistance of our BCA to adverse environmental factors, including water activity and low relative humidity for its eventual application in pre-harvest conditions. This could be done without using a sugar together with SM. As a result, further trials will be planned to assess the effectiveness of a formulation based on the strain $\mathrm{O}$ in combination with SM and trehalose under field conditions at least $48 \mathrm{~h}$ before harvesting.

\section{Acknowledgments}

This manuscript is a part of my doctoral research performed at Plant Pathology Unit of Gembloux Agricultural University. The authors are grateful to my colleagues Drs. M. Sabar and J. Puigagut (IRBV, Montreal University) for reviewing this manuscript.

\section{References}

Abadias, M., Teixidõ, N., Usall, J., Benabarre, A., Viñas, I., 2001. Viability, efficacy, and storage stability of freeze-dried biocontrol agent Candida sake using different protective and rehydration media. Journal of Food Protection 64, 856-861.

Berny, J.F., Hennebert, G.L., 1991. Viability and stability of yeast cells and filamentous fungus spores during freeze drying: effects of protectants and cooling rates. Mycologia 83, 805-815.

Bonaterra, A., Camps, J., Montesinos, E., 2005. Osmotically induced trehalose and glycine betaine accumulation improves tolerance to desiccation, survival and efficacy of the postharvest biocontrol agent Pantoea agglomerans EPS125. FEMS Microbiology Letters 250, 1-8.

Champagne, C.P., Gardner, N., Brochu, E., Beaulieu, Y., 1991. The freeze drying of lactic acid bacteria: a review. Canadian Institute of Science and Technology 24, $118-128$.

Crowe, J.H., Carpenter, J.F., Crowe, L.M., Anchordoguy, T.J., 1990. Are freezing and dehydration similar stress vector? A comparison of modes of interaction of stabilizing solutes with biomolecules. Cryobiology 27, 219-231.

Csonka, L.N., 1989. Physiological and genetic response of bacteria to osmotic stress. Microbiological Review 53, 121-147.

Font de Valdez, G., de Giori, G.S., de Ruiz Holgado, A.P., Oliver, G., 1983. Comparative study of the efficiency of some additives in protecting lactic acid bacteria against freeze drying. Cryobiology 20, 560-566.

Hallsworth, J.E., Magan, N., 1996. Culture age, temperature, and $\mathrm{pH}$ affect the polyol and trehalose contents of fungal propagules. Applied and Environmental Microbiology 6, 2435-2442.

Hanafusa, J.V., 1985. The hydration water and protein with cryoprotectant. In: Fundamentals and Applications of Freeze Dried to Biological Materials, Drugs and Food Stuffs, International Institute of Refrigeration, Paris, p. 59

Ippolito, A., Nigro, F., 2000. Impact of preharvest application of biological control agents on postharvest diseases of fresh fruits and vegetables. Crop Protection 19, 715-723.

Jijakli, M.H., Lepoivre, P., Tossut, P., Thonard, P., 1993. Biological control of Botrytis cinerea and Penicillium sp. on post-harvest apples by two antagonistic yeasts. Med. Fac. Landboww. Univ. Gent. 58/3b, 1349-1358.

Jijakli, M. H., Dickburt, C., De Clercq, D., Lepoivre, P., 2002. Application de Pichia anomala souche K, 1, 3-Glucanes et chlorure de calcium pour le contrôle des maladies de conservation des pommes en conditions proches de la pratique. In: 2ème Conférence Internationale sur les moyens alternatifs contre les organismes nuisibles aux végétaux. Palais du Nouveau siècle, Lille-France, pp. 436-445.

Jijakli, M.H., Lepoivre, P., 1998. Characterization of an exo- $\beta-1$, 3-glucanase produced by Pichia anomala strain K, antagonist of Botrytis cinerea on apples. Phytopathology 88, 335-343.

Kown, H.B., Yeo, E.T., Hahn, S.E., Bae, S.C., Kim, D.Y., Byun, M.O., 2003. Cloning and characterization of genes encoding trehalose-6-phosphate synthase (TPS1) and trehalose-6-phosphate phosphatase (TPS2) from Zygosaccharomyces rouxii. FEMS Yeast Research 3, 433-440.

Lahlali, R., Firel, D., Jijakli, M.H., 2007b. Comparative study of the ecological niche of Penicillum expansum, Botrytis cinerea and their antagonistic yeasts Candida oleophila strain O and Pichia anomala strain K. IOBC/wprs Bulletin 30 (6), 237239.

Lahlali, R., Firel, D., Serrhini, M.N., Jijakli, M.H., 2006b. Effect of incubation temperature and relative humidity on lesion diameter of Botrytis cinerea Pers. and Penicillium expansum Link. on apple fruits. Communications in Agricultural and Applied Biological Sciences 71, 1159-1166.

Lahlali, R., Firel, D., Serrhini, M.N., Jijakli, M.H., 2007a. Predictive modelling of temperature and water activity (solutes) on the in vitro radial growth of Botrytis cinerea Pers. International Journal of Food Microbiology 114, 1-9.

Lahlali, R., Massart, S., De Clercq, D., Serrhini, M.N., Creemers, P., Jijakli, M.H., 2009. Assessment of Pichia anomala (strain K) efficacy against blue mould of apples when applied pre- or postharvest under laboratory conditions and in orchard trials. European Journal of Plant Pathology 123, 37-45.

Lahlali, R., Massart, S., Serrhini, M.N., Jijakli, M.H., 2008. A Box-Behnken design for predicting the combined effects of relative humidity and temperature on antagonistic yeast population density at the surface of apples. International Journal of Food Microbiology 122, 100-108.

Lahlali, R., Serrhini, M.N., Friel, D., Jijakli, M.H., 2006a. In vitro effects of water activity, temperature, and solutes on the growth rate of $P$. italicum Wehmer and P. digitatum Sacc. Journal of Applied Microbiology 101, 628-636.

Lahlali, R., Serrhini, M.N., Jijakli, M.H., 2004. Efficacy assessment of Candida oleophila (strain O) and Pichia anomala (strain K) against major postharvest diseases of 
citrus fruits in Morocco. Communications in Agricultural and Applied Biological Sciences 69 (4), 601-609.

Lahlali, R., Serrhini, M.N., Jijakli, M.H., 2005a. Studying and modelling the combined effect of water activity and temperature on growth rate of $P$. expansum. International Journal of Food Microbiology 103, 315-322.

Lahlali, R., Serrhini, M.N., Jijakli, M.H., 2005b. Development of a biological control method against postharvest diseases of citrus fruits. Communications in Agricultural and Applied Biological Sciences 70 (3), 47-58.

Li, B.Q., Tian, S.P., 2006. Effects of trehalose on stress tolerance and biocontrol efficacy of Cryptococcus laurentii. Journal of applied Microbiology 100, 854861.

Li, B.Q., Tian, S.P., 2007. Effect of intracellular trehalose in Cryptococcus laurentii and exogenous lyoprotectants on its viability and biocontrol efficacy on Penicillium expansum in apple fruit. Letters in Applied Microbiology 44, 437442.

Magan, N., 2001. Physiological Approaches to Improving the Ecological Fitness of Fungal Biocontrol Agents. Fungi as Biocontrol Agents. Progress, problems and Potential. CABI Publishing, Bristol, 390 p.

Massart, S., De Clercq, D., Salmon, M., Dickburt, C., Jijakli, M.H., 2005. Development of real-time PCR using Minor Groover Binding probe to monitor the biological control agent Candida oleophila (strain O). Journal of Microbiological Methods $60,73-82$.
Mercier, J., Wilson, C.L., 1995. Effect of wound moisture on the biocontrol by Candida oleophila of gray mold rot (Botrytis cinerea) of apple. Postharvest Biology and Technology 6, 9-15.

Miller, K.J., Wood, J.M., 1996. Osmoadaptation by rhizosphere bacteria. Annual Reviews of Microbiology 45, 569-606.

Potts, M., 1994. Dessication tolerance of prokaryotes. Microbiological Review 58, $755-805$.

Ray, B., Jezeski, JJ., Busta, FF., 1971. Effect of rehydration on recovery, repair and growth of injured freeze-dried Salmonella anatum. Applied Microbiology 22 $184-189$.

Teixidõ, N., Usall, J., Vinãs, I., 1999. Efficacy of preharvest and postharvest Candida sake biocontrol treatments to prevent blue mould on apples during cold storage. International Journal of Food Microbiology 50, 203-210.

Teixidõ, N., Vinãs, I., Usall, J., Magan, N., 1998b. Improving ecological fitness and environmental stress tolerance of the biocontrol yeast Candida sake by manipulation of intracellular sugar alcohol and sugar content. Mycological Research 102, 1409-1417.

Teixidõ, N., Vinãs, I., Usall, J., Sanchis, V., Magan, N., 1998a. Ecophysiologica responses of the biocontrol yeast Candida sake to water, temperature and stress. Journal of Applied Microbiology 84, 192-200.

Zayed, G., Roos, Y.H., 2004. Influence of trehalose and moisture content on survival of Lactobacillus salivarius subjected to freeze-drying and storage. Proces Biochemistry 39, 1081-1086. 